\title{
Microstructural damage evaluation of ferritic-ausferritic spheroidal graphite cast iron
}

\author{
D. O. Fernandino, N. Tenaglia, R. E. Boeri \\ INTEMA, Universidad Nacional de Mar del Plata-CONICET, Av. Colón 10850, Mar del Plata, B7606BVZ, Argentina \\ dfernandino@fi.mdp.edu.ar, bttps://orcid.org/0000-0003-4647-2663 \\ ntenaglia@fi.mdp.edu.ar, bttp://orcid.org/0000-0001-6372-88816372-8881 \\ boeri@fi.mdp.edu.ar, bttp://orcid.org/0000-0001-7083-579X579X
}

\author{
V. Di Cocco, C. Bellini, F. Iacoviello \\ Università di Cassino e del Lazio Meridionale, DiCeM, via G. Di Biasio 43, 03043 Cassino (FR), Italy. \\ vittorio.dicocco@unicas.it, http://orcid.org/0000-0002-1668-3729 \\ costanzo.bellini@unicas.it, bttp://orcid.org/0000-0003-4804-6588 \\ francesco.iacoviell@@unicas.it, http:/ / orcid.org/0000-0002-9382-6092
}

\begin{abstract}
The goal of this work is to improve the understanding of the relation between the microstructural characteristics of Intercritical Austempered Ductile Cast Iron (IADI) and the damage micromechanisms observed during its tensile loading. The experimental methodology involves heat treatments to obtain IADI and the assessment of the damage mechanisms (sequence and occurrence) during step by step tensile testing. The damage evaluation was carried out by observing the surface of the tensile test specimen with optical and scanning electron microscopy.

The results show that small cracks start forming soon after the yield stress is surpassed. The crack initiation is preferentially located at matrix-nodule interface. As loading increases, cracks also develop at the ferritic grain boundaries and the ausferritic/ferritic interfaces. Consequently, at higher strain values, a competition between the plastic deformation on internodular zones and crack propagation along ausferritic phase is observed.

Finally, the final fracture is produced by the propagation of cracks across the internodular ligaments and through the ausferritic/ferritic interface that later coalesce into a single dominant crack leading to the material failure.
\end{abstract}

KEYwORDS. Spheroidal Graphite Cast Iron; Fracture mechanisms; Intercritical ADI; Tensile test.

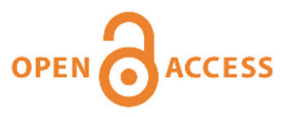

Citation: Fernandino, D. O., Di Cocco, V., Tenaglia, N., Bellini, C., Iacoviello, F., Boeri, R. E. Microstructural damage evaluation of ferritic-ausferritic spheroidal graphite cast iron, Frattura ed Integrità Strutturale, 51 (2020) 477-485.

Received: 10.11.2019

Accepted: 12.12 .2019

Published: 01.01.2020

Copyright: (C) 2020 This is an open access article under the terms of the CC-BY 4.0, which permits unrestricted use, distribution, and reproduction in any medium, provided the original author and source are credited. 


\section{INTRODUCTION}

$\mathrm{S}$ pheroidal Graphite cast Iron (SGI) is a kind of cast material which covers a wide range of mechanical properties via microstructural control. SGI can be produced with ferritic, pearlitic, martensitic or ausferritic matrices depending on its chemical composition and processing. The SGI with ausferritic matrix is usually obtained after an austempering heat treatment and it is called Austempered Ductile Iron (ADI). It shows very high strength and acceptable toughness. These characteristics, together with the relatively low cost and ease of production, make SGI and ADI to be increasingly used in the construction of high stressed parts for machines and vehicles [1]. However, as most structural materials nowadays, SGI faces a strong competition from different materials available for similar applications. In this context, over the last 10 years, increasing attention has been given to the development of a new kind of SGI, referred to as Intercritical Austempered Ductile Iron (IADI) or sometimes as Dual-Phase Austempered Ductile Iron (DPADI) [2-4]. The metallic matrix of this material is formed by different amounts of ausferrite (a fine mix of ferrite and austenite) and free-ferrite. The aim of this development is to bridge the gap existing between the properties of the pearlitic grades of SGI and the much stronger ADI grades, by producing materials with similar strength as the pearlitic grades but displaying greater toughness and better machinability.

The usual methodology used to produce IADI consists of submitting SGI to a partial austenitization by heating within the ternary ferrite-austenite-graphite phase field, followed by an austempering treatment [3-5]. Depending on the intercritical temperature selected, different amounts of austenite will be present in the sample before cooling. The subsequent austempering aims at transforming the austenite into a mixture of acicular ferrite and retained austenite, sometimes referred to as "ausferrite", while leaving the ferrite untransformed. Thus, after heat treatment, the metallic matrix of IADI is composed of ausferrite and free ferrite. Under this experimental procedure, the relative amounts and morphology of ferrite and ausferrite can be controlled by using different austenitizing temperatures and thermal cycles. The literature reports several experimental procedures and considerations to obtain IADI [2-5] and different mechanical properties based on the amount of ferrite and ausferrite [6-8]. In general, tensile strength, yield stress, and fracture toughness increase when the amount of ausferrite increases, while elongation diminishes. Nevertheless, such a decrease is very small and the IADI keep having the minimum value of elongation required by ASTM A 536 standard.

The fracture surfaces of IADI for different amounts of ferrite-ausferrite were also evaluated by several authors [8-9], nevertheless, there is not a complete understanding about the sequence and occurrence of damage mechanisms, nor about the influence of the ausferrite (in terms of morphology and volume fraction) on crack propagation and damage evolution. Recent studies carried out by the authors improved the understanding of the role of different microconstituents during fatigue and tensile testing by means of in-situ analysis [10-13]. This procedure provides a direct observation of the damage evolution of IADI. In consequence, in this work, a step by step analysis of IADI samples during tensile testing is carried out with the main goal of improving the understanding of the relation between the microstructure of IADI and the damage micromechanisms under tensile loading.

\section{MATERIAL AND METHODS}

$\mathrm{T}$ he Spheroidal Graphite Cast Iron (SGI) samples were taken from $25 \mathrm{~mm}$ "Y" blocks of a melt used in a previous work [14]. The SGI material was submitted to a ferritizing annealing following standard heat treatment procedures [15]. The annealing is commonly used to standardize the starting microstructure of the samples to be heat treated to obtain IADI. Electrical furnaces were employed to carry out the austenitization and ferritization heat treatments and $500 \mathrm{~kg}$ of low-melting-point salt bath $\left(50 \% \mathrm{NaNO}_{2}\right.$ and $\left.50 \% \mathrm{KNO}_{3}\right)$ were used for the austempering treatments.

\section{Determination of the intercritical temperature interval}

The determination of the upper and lower temperatures of the ferrite-austenite-graphite phase field is necessary to properly select the heat treatment temperature to obtain the desired IADI microstructure. In consequence, the kinetics of austenite transformation as a function of the heating temperature was investigated. Several $10 \mathrm{~mm}$ diameter cylinders were heated and held for one hour at temperatures in the range of $720-900{ }^{\circ} \mathrm{C}$, at steps of $20^{\circ} \mathrm{C}$. After the holding stages were completed, each sample was quenched in water. They were then sectioned and prepared for metallographic observation. The microconstituents were quantified (\% in volume) by using an optical microscope and the Image Pro Plus software. Reported values are the average of at least three determinations. The graphite areas were not accounted for in the reported percentage of the microconstituents. 
Once the advance of the austenite precipitation within the intercritical temperature range was characterized, this information was used to design the heat treatment cycle aimed at producing a microstructure consisting of $60 \%$ ferrite and $40 \%$ ausferrite. The heat treatment consisted of a partial austenitization of the ferritic samples, by holding them into the furnace within the intercritical interval at the selected temperature for one hour, followed by an austempering step in a salt bath at $350^{\circ} \mathrm{C}$ for $90 \mathrm{~min}$.

\section{Tensile test sample}

A very small-size specimens were machined from the calibrated zone of one-inch Y block. Then, samples were ground to $1 \mathrm{~mm}$ in thickness and polished using standard procedures. The dimensions of the small tensile specimen are shown in Fig. 1.

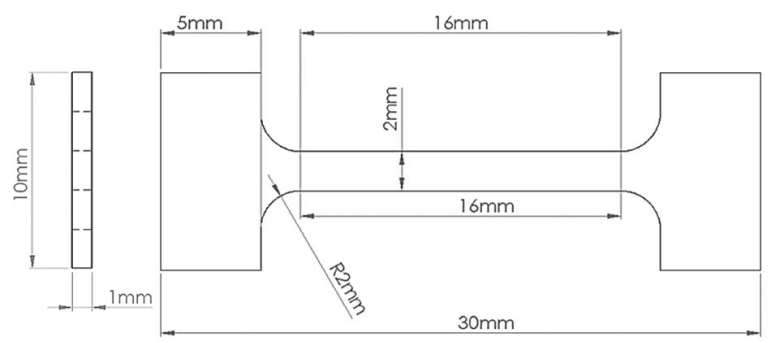

Figure 1: Dimensions of the small-size tensile test specimen.

\section{Step by step damage evolution}

The small-size tensile samples were tested by using a tensile testing device specially designed to perform a step by step analysis (Fig. 2). The tensile device includes a Linear Variable Differential Transformer (LVDT) and two miniature load cells $(10 \mathrm{kN}$ each). The device is prepared to perform a step by step loading, keeping the load constant within steps by means of the tensile holder as is shown in the magnification of Fig. 2. The samples are then loaded to some specific value and then examined at microstructural level using both Light Optical Microscopy and SEM. The microscopic observations were conducted "in-situ" by using a digital microscope Leica VZ105C equipped with a digital microscope camera Leica DVM2000 and a SEM Philips 505.

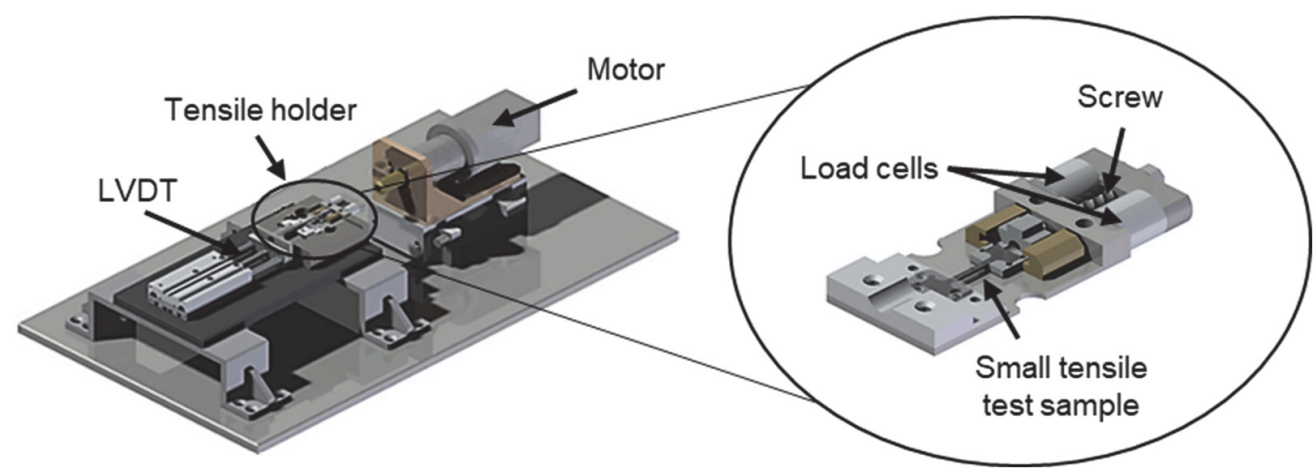

Figure 2: Schematization of the tensile test device designed to perform step by step tensile tests. The magnification area shows tensile holder details.

\section{RESULTS}

\section{Material characterization and intercritical temperature interval}

amples of the same melt used in this study were also used by Fernandino and Boeri [14]. The chemical composition is listed in Tab. 1. After the pre-conditioning annealing, a fully ferritic metallic matrix was achieved. The microstructures obtained after heating the samples at three different temperatures within the intercritical interval and quenched in water are shown in Fig. 3. The metallographies show ferrite (white), graphite (black), and martensite (gray). The martensite is formed after quenching of the austenite present at the austenitization temperature; therefore, its amount 
indicates the amount of austenite at the selected heating temperature within the intercritical temperature interval. In consequence, as the heating temperature increases, the amount of martensite also increases. The fraction of austenite formed as a function of the temperature is shown in Fig. 4.

Based on this information, a heating temperature of $788^{\circ} \mathrm{C}$ was selected to achieve an IADI with $60 \%$ Ferrite and 40\%Ausferrite after the austempering heat treatment. Fig. 5 shows the resulting microstructure after the austempering from the intercritical heating temperature. The metallographies show ferrite (white), graphite (black), and ausferrite (gray).

\begin{tabular}{ccccccc}
\hline $\mathrm{C}$ & $\mathrm{Si}$ & $\mathrm{Mn}$ & $\mathrm{S}$ & $\mathrm{P}$ & $\mathrm{Mg}$ & $\mathrm{Cu}$ \\
3.32 & 2.36 & 0.31 & 0.012 & 0.016 & 0.033 & 0.62 \\
\hline
\end{tabular}

Table 1: Chemical composition of DI used (weight $\%$, Fe balance).

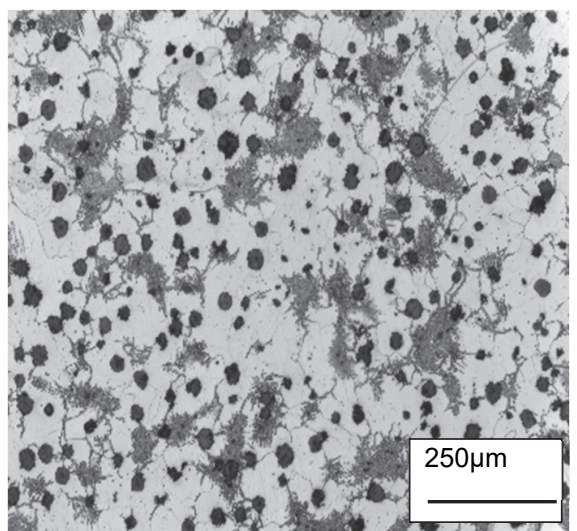

(a)

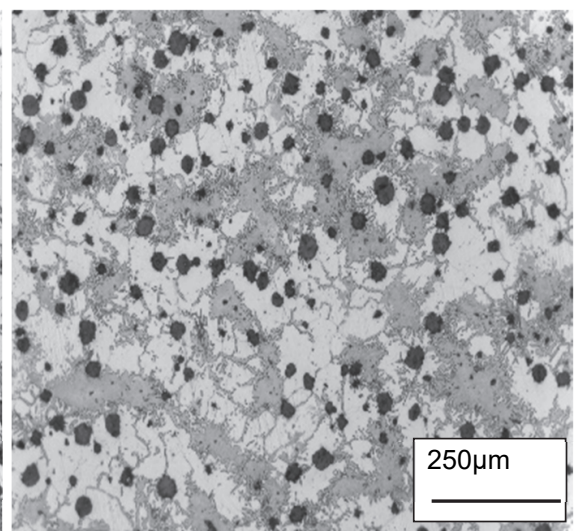

(b)

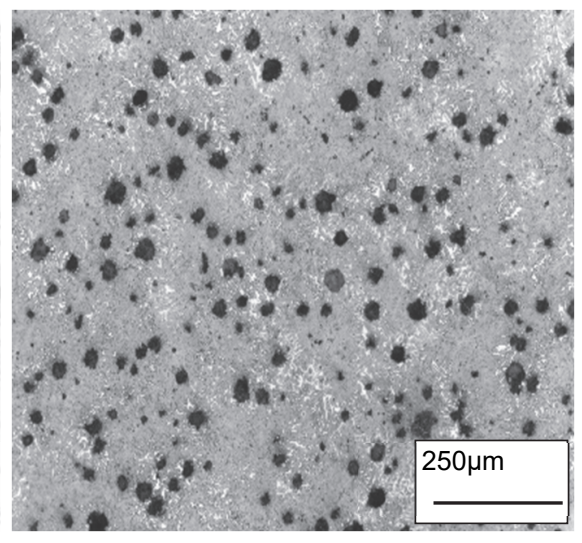

(c)

Figure 3: Metallographies after rapid quenching of samples heated up to different temperatures and maintained for $60 \mathrm{~min}$. (100×). (a) $780{ }^{\circ} \mathrm{C}$, (b) $800^{\circ} \mathrm{C}$, (c) $840{ }^{\circ} \mathrm{C}$.

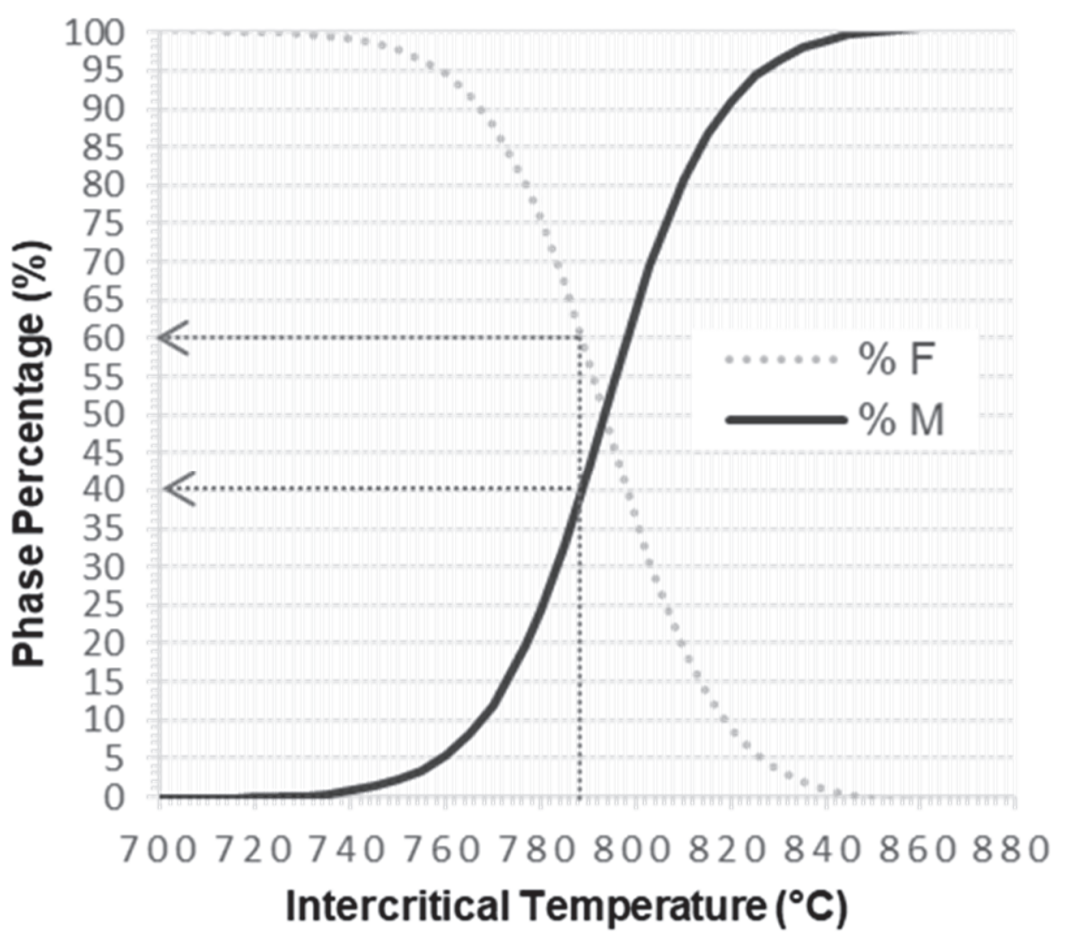

Figure 4: The kinetics of austenite transformation as a function of the temperature. 


\section{Micro-scale damage evolution}

Fig. 6 shows a sequence of metallographic observation of the micro-scale damage evolution during the step by step loading procedure, at different engineering strains $\left(\varepsilon_{\text {eng }}\right)$. Both optical micrographies (I) and SEM images (II) are shown.

As shown in Fig. 6a, for $\varepsilon_{\text {eng }}=0.004$, the microstructural damage involves two features: crack initiation at the matrix-nodule interface (MNI), see the magnification of Fig. 6a-II, and the beginning of plastic deformation marks, mostly located near the graphite nodules which are generally surrounded by ferrite.

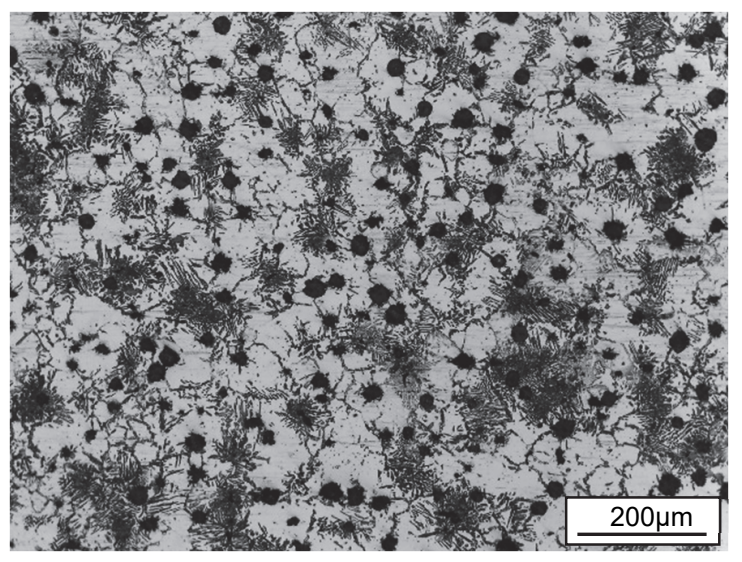

Figure 5: Microstructure after the austempering from the partial austenitization temperature.

As the macroscopic strain rises to 0.02, Fig. 6b, complete Matrix-Nodule interface Debonding (MND) takes place, while signs of plastic deformation bands and crack initiation at the metallic matrix are observed along the whole sample surface. White arrows in Fig. 6b-I and II point out some sites of crack initiation. The MND mechanism was generally observed as a separation of the MNI with a very thin layer of graphite remaining bonded to the interface, as it is shown in Fig. 6b-II. It is worthy to note that generally, the graphite nodules were surrounded by ferritic phase (previously obtained by an annealing heat treatment) and this observation is in agreement with those of D'Agostino et al (2017) [11] who proposed that when the ferritic microstructure of SGI is obtained by means of an annealing heat treatment, the damaging mechanism of MNI is characterized by the debonding of the surface of the as-cast nodules and the thin carbon layer formed on the surface of those nodules during the ferritization process. However, an "onion-like" fracture mechanism is generally reported when ferritic microstructure is obtained from as-cast condition $[9,10]$.

For $\varepsilon_{\text {eng }}=0.1$, the evolution of plastic damage mechanisms in the metallic matrix and the beginning of crack propagation is observed (in Fig. 6c and d). As the strain rises to $\varepsilon_{\text {eng }}=0.14$, Fig. 6e, the crack propagation is observed preferentially at ferritic grain boundary or at the ausferritic-ferritic interface in an attempt to propagate along it. An example of crack tending to follow the ausferrite acicular morphology during the propagation is pointed out by a white arrow in the magnification in Fig. 6e-II. Additionally, an optical micrograph showing a crack initiation at a ferritic grain boundary (pointed out by a white arrow) surrounded by signs of plastic deformation is presented in Fig. 7.

The final fracture was reached at $\varepsilon_{\text {eng }}=0.152$, Fig. 6f. The internodular zones tend to localize the plastic deformation, acting as predominant sites for crack initiation and propagation, as it was also reported by the authors for ferritic SGI [13]. However, in the IADI evaluated, it is observed that ausferrite and ausferrite-ferrite interfaces also act as sites for crack initiation and propagation. Consequently, the final fracture is produced by crack propagation across the internodular ligaments and along the ausferrite, that later coalesce into a single dominant crack leading to the material failure. Similarly to the observation reported by the authors for ferritic SGI [13], MND and some sites of crack initiation at regions that are not involved in the final failure crack are also evidenced (magnification of Fig. 6f-II). However, the plastic deformation observed in this investigation was smaller than that reported for ferritic SGI, which is consistent with the lower strain value for the final fracture. Accordingly, it is possible to argue that as the ausferrite fraction increases, the amount of plastic damage mechanisms at both the final fracture and near the final crack decrease.

The resulting fracture surface, Fig. 8a, shows a combination between the well-known ductile damage mechanism of Ferritic SGI $[13,15,17]$ and quasi-cleavage fracture mechanism for ADI $[16,17]$ resulting from quasi-static loading conditions. These observations support that there is a competition between the plastic deformation at the internodular zones and the crack propagation along the ausferrite during fracture. 

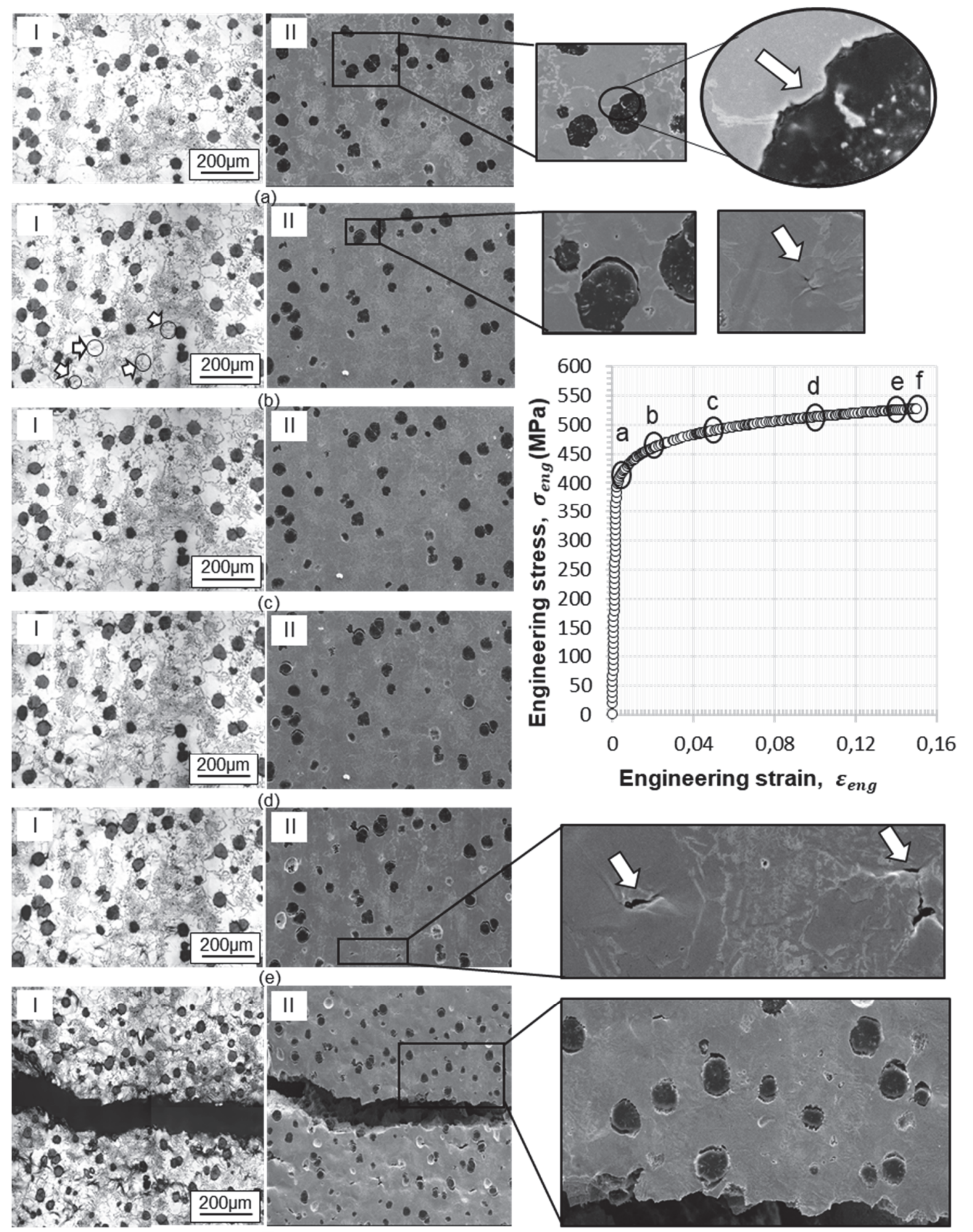

(f)

Figure 6: Sequence of metallographic observation of the micro-scale damage evolution during the step by step procedure at different engineering strains $\left(\varepsilon_{\text {eng }}\right)$. I-Optical micrographies, II-SEM images. (a) $\varepsilon_{\text {eng }}=0.04$, (b) $\varepsilon_{\text {eng }}=0.2$, (c) $\varepsilon_{\text {eng }}=0.5$, (d) $\varepsilon_{\text {eng }}=0.10$, (e) $\varepsilon_{\text {eng }}=$ 0.14 , (f) $\varepsilon_{\text {eng }}=0.152$.

Magnifications of different areas of the fracture surfaces in Fig. 8a are presented in Fig. 8b,c and d. A detail of a quasicleavage facet is shown in Fig. 8d. It is important to note the tearing between the cleavage facets. These tearing is a result 
of the quasi-cleavage fracture mechanism itself, where the fracture initiates along the cleavage facets and is followed by plastic strain of the remaining ligament. This is the main difference with a classical cleavage facet, in which the fracture process is characterized by the separation of the cleavage planes through its edges [18].

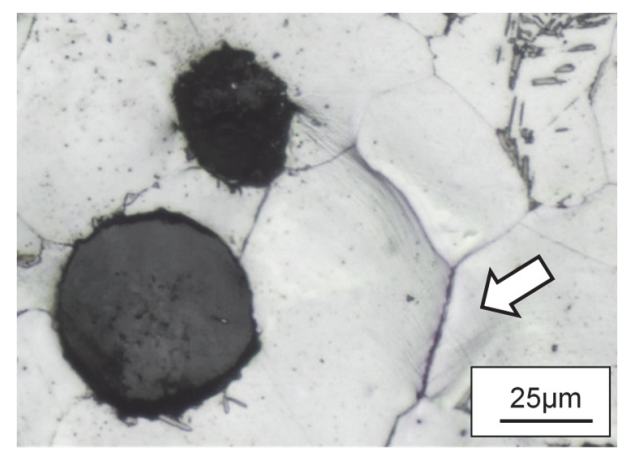

Figure 7: Optical micrography showing a crack initiation at a ferritic grain boundary. Engineering strains, $\boldsymbol{\varepsilon}_{\mathrm{eng}}=0.10$.

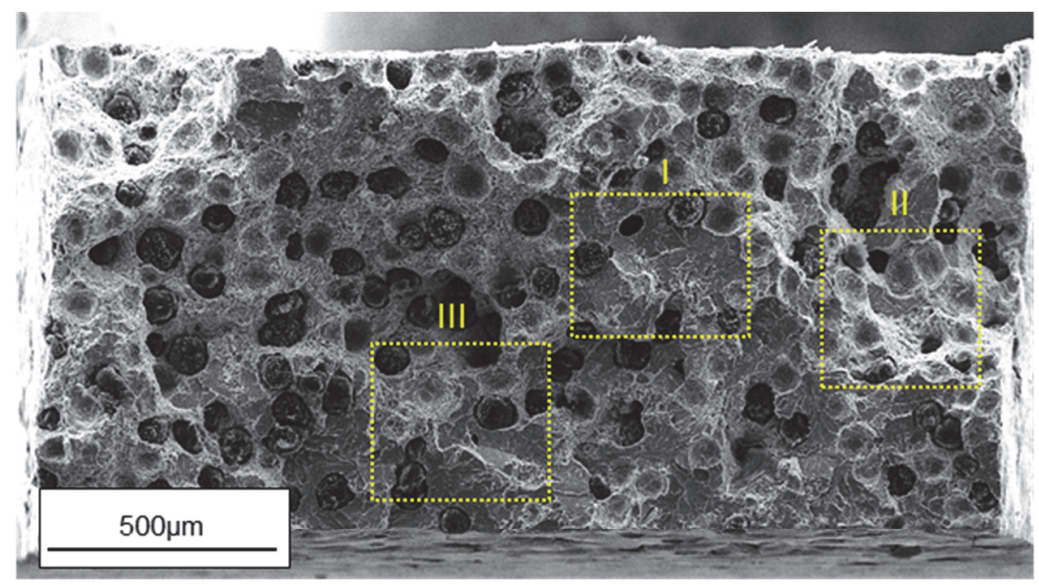

(a)

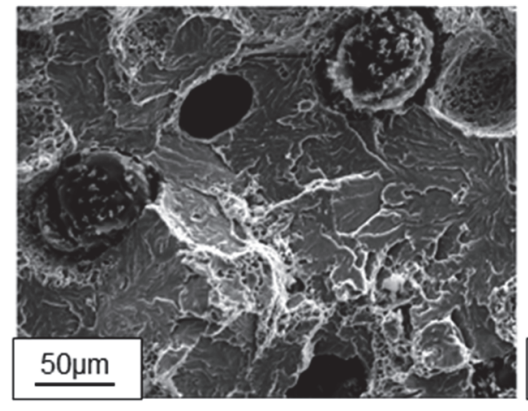

(b)

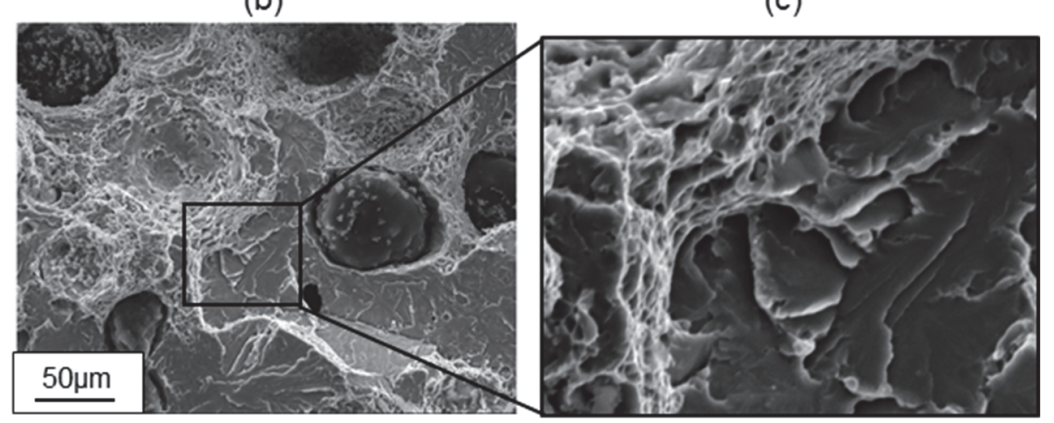

(d)

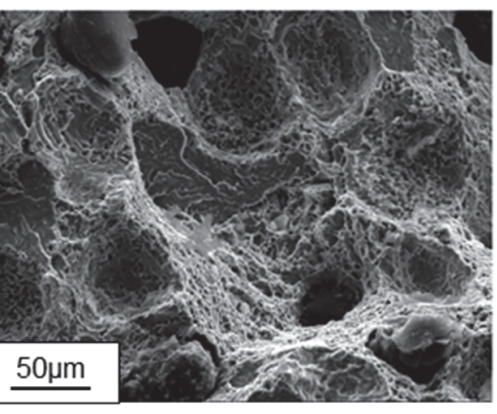

(c)

Figure 8: Fracture surface of the small tensile sample resulting from the quasi-static loading condition. Different magnifications. 


\section{CONCLUSIONS}

A $\mathrm{n}$ analysis of the microstructural damage mechanisms induced by tensile loading on intercritically austempered ductile iron (IADI) has been presented. The main findings are:

At the beginning of the deformation, the crack initiation is preferentially located at matrix-nodule interface. Then, as strain increases, the crack initiation is also observed at ferritic grain boundaries and at the ausferrite-ferrite interface.

- During the damage evolution, a competition between the plastic deformation on internodular zones and crack propagation along ferritic grain boundaries and ausferritic phase takes place.

- A mix of ductile and quasi-cleavage fracture surfaces is observed under the experimental procedure carried out. These characteristics of the fracture surfaces are consistent with those resulting from quasi-static loading conditions on ferritic SGI and ADI, respectively.

- The final fracture is produced by crack propagation across the internodular ligaments and along the ferritic grain boundaries and ausferrite, that later coalesce into a single dominant crack leading to the material failure.

- Further investigations considering different proportions of ausferrite-ferrite and the characterization of the crystallographic direction of the ausferrite phase respect to the crack propagation should be undertaken, in order to generalize the validity of these results.

\section{ACKNOWLEDGEMENTS}

7 his research has been supported by grants awarded by CONICET-CUIA (Bilateral Cooperation Program-2017), ANPYCT (PICT 2016-3838), the National University of Mar del Plata (ING 458/16).

\section{REFERENCES}

[1] Ductile Iron Society. Ductile Iron Data for Design Engineers. Rio Tinto Iron \& Titanium, Inc.1998.

[2] Aranzabal, J., Serramoglia, G. and Rousiere, D. (2002). Development of a new mixed (ferritic-ausferritic) ductile iron for automotive suspension parts, Int. J. Cast. Metal. Res. 16 (1), pp. 185-190. DOI: 10.1080/13640461.2003.11819580.

[3] Basso, A., Martínez, R.A. and Sikora, J.A. (2006). Development of dual phase ADI. Proceedings of the Eighth International Symposium on Science and Processing of Cast Iron, Beijing, China, 16-19 October.

[4] Aristizabal, R., Hayrynen, K., Foley, R., Griffin, J. and Monroe, C. (2014). Austemperability of Intercritically Austempered Ductile Iron (IADI). AFS Transactions, American Foundry Society, Schaumburg, IL USA. pp. 279-286.

[5] Fernandino, D.O., Massone, J.M. and Boeri, R.E. (2013). Characterization of the austemperability of partially austenized ductile iron, J. Mater. Process. Tech., 213, pp. 1801-1809. DOI: 10.1016/j.jmatprotec.2013.05.002.

[6] Panneerselvam, S., Putatunda, K., Gundlach, R. and Boileau, J. (2017). Influence of intercritical austempering on the microstructure and mechanical properties of austempered ductile cast iron (ADI), Mat. Sci. Eng. A-Struct., 694, pp. 72-80. DOI: 10.1016/j.msea.2017.03.096.

[7] Chen, J.K., Chen, B.T. and Tsai, J.S. (2016). Microstructural evolutions and properties of partially austenitizing and austempered ductile irons, Steel Res. Int., 87 (2), pp. 191-198. DOI: 10.1002/srin.201400603.

[8] Basso, A., Sikora, J. and Martínez, R. (2013). Analysis of mechanical properties and its associated fracture surfaces in dual-phase austempered ductile iron, Fatigue Fract. Eng. Mater. Struct., 36 (7), pp. 650-659.

DOI: https://doi.org/10.1111/ffe.12032

[9] Kilicli, V. and Erdogan, M. (2010). The nature of the tensile fracture in austempered ductile iron with dual matrix microstructure, J. Mater. Eng. Perform., 19, pp. 142-149. DOI: 10.1007/s11665-009-9386-x.

[10] Iacoviello, F., Di Cocco V. and Cavallini, M. (2016). Fatigue crack propagation and overload damaging micromechanisms in a ferritic-pearlitic ductile cast iron, Fatigue Fract. Eng. Mater. Struct., 39(8), pp. 999-1011. DOI: $10.1111 /$ ffe.12443.

[11] Iacoviello, F., Di Cocco, V., Rossi, A. and Cavallini, M. (2013). Pearlitic ductile cast iron: damaging micromechanisms at crack tip, Fract. Struct. Integr., 7(25), pp. 102-108. DOI: 10.3221/IGF-ESIS.25.15. 
[12] D’Agostino, L., Di Cocco, V., Fernandino, D.O. and Iacoviello, F. (2017). Damaging micromechanisms in an as cast ferritic and a ferritized ductile cast iron, Proc. Struct. Integr., 3, pp. 201-207. DOI: 10.1016/j.prostr.2017.04.045

[13] Fernandino, D.O. and Boeri, R.E.,(2019). In-situ microscopic analysis of ferritic ductile iron during tensile loading Relation between matrix heterogeneities. Fatigue Fract. Eng. Mater. Struct., 42, pp. 2220-2231. DOI: $10.1111 /$ ffe.13030.

[14] Fernandino, D.O. and Boeri, R.E. (2015). Fracture of pearlitic ductile cast iron under different loading conditions. Fatigue Fract. Eng. Mater. Struct., 38, pp. 80-90. DOI: 10.1111/ffe.12220.

[15] Fernandino, D.O. and Boeri, R.E. (2015). Study of the fracture of ferritic ductile cast iron under different loading conditions. Fatigue Fract. Eng. Mater. Struct., 38, pp. 610-620. DOI: 10.1111/ffe.12266.

[16] Fernandino, D.O and Boeri, R.E (2015). Fractographic analysis of austempered ductile iron. Fatigue Fract. Eng. Mater. Struct., 39, pp. 583-598. DOI:10.1111/ffe.12380.

[17] Martínez, R.A (2010). Fracture surfaces and the associated failure mechanisms in ductile iron with different matrices and load bearing, Eng Fract Mech., 77(14), pp. 2749-2762. DOI: 10.1016/j.engfracmech.2010.07.013.

[18] Ipohorski, M. and Acuña, R.J. (1988). Fractografía. Aplicación al Análisis de Fallas, Buenos Aires: Comisión Nacional de Energía Atómica. 